\title{
Androstenedione and testosterone concentrations in plasma and milk of the cow throughout pregnancy
}

\author{
Rosella Gaiani, F. Chiesa, M. Mattioli, G. Nannetti and Giovanna Galeati \\ Istituto di Fisiologia Veterinaria e Cattedra di Fisiologia generale e Speciale Veterinaria II e Fisica \\ Biologica, Università degli Studi di Bologna, Via Belmeloro, 8/2, Bologna, Italy
}

\begin{abstract}
Summary. Androstenedione concentrations in both plasma and milk were higher than those of testosterone throughout pregnancy. Testosterone concentration increased during pregnancy; the levels in milk were always lower than in plasma. Androstenedione concentrations increased in plasma and milk during pregnancy but the values were twice as high in milk as in plasma after Day 90. This change in androstenedione distribution suggests that the mammary gland could be active in the uptake of androstenedione from plasma to milk or that the mammary gland itself might synthesize this hormone.
\end{abstract}

\section{Introduction}

There are few reports on the peripheral plasma levels of androgens in pregnant cows. Plasma testosterone concentrations were studied by Hoffman, Wagner \& Gimenez (1976) in cows at term and by Pflantz, Stallcup \& Kreider (1981) in cows at 4-8 months of pregnancy. Mongkonpunya, Lin, Noden, Oxender \& Hafs (1975) measured androstenedione and testosterone values at 90, 180 and 260 days of gestation, and Möstl et al. (1981) those of testosterone, epitestosterone and androstenedione in cows around parturition. However, the rapid enzymic conversion of androstenedione to epitestosterone that occurs in bovine blood after its collection (Lindner, 1961; Bamberg, Choi \& Möstl, 1978; Möstl, Choi \& Bamberg, 1980) makes the accurate estimation of androstenedione quite difficult. Möstl et al. (1981) added methanol to blood samples to inhibit this enzymic conversion.

Androgens are also present in the milk of pregnant cows (Gaiani, Nannetti \& Mattioli, 1979) and in the present study we have examined the variations in androstenedione and testosterone in plasma and milk throughout pregnancy of the cow and tried to evaluate the relationship between these hormones.

\section{Materials and Methods}

\section{Animals and sampling}

The 54 Holstein-Friesian cows were 10-270 days of gestation. Animals belonging to the same commercial herd were regularly milked twice a day until about Day 200 of pregnancy. Two blood samples were taken from each cow, by jugular venepuncture, after the morning milking. The first blood sample was collected in a heparinized tube and used for testosterone determination. The other blood sample was collected directly into a heparinized tube containing methanol $(0 \cdot 17 \mathrm{ml} / \mathrm{ml}$ blood) and used for androstenedione determination. 
A whole milk sample, at the morning milking, was taken from the milk reservoir collected from each animal after thorough mixing.

Plasma and milk were stored at $-20^{\circ} \mathrm{C}$ until assayed.

In preliminary experiments we confirmed that great differences in plasma androstenedione levels occurred in samples collected with and without methanol addition, as reported by Bamberg $e t$ al. (1978) and Möstl et al. (1980), but there were no differences in milk androstenedione concentrations in samples collected with and without methanol.

\section{Extraction procedures}

Plasma. Testosterone and androstenedione were extracted from the plasma $(0.5 \mathrm{ml})$ with diethyl ether $(7 \mathrm{ml})$ after addition of about 1000 c.p.m. $\left[1,2,6,7-{ }^{3} \mathrm{H}\right]$ testosterone or $\left[1,2,6,7-{ }^{3} \mathrm{H}\right]$ androstenedione (labelled steroids were purchased from New England Nuclear, West Germany). The extract was dried and the residue was redissolved in $500 \mu 10.05 \mathrm{M}-\mathrm{PBS}-\mathrm{EDTA}, \mathrm{pH} \mathrm{7.5}$, containing $0 \cdot 1 \%$ BSA. Two samples of $100 \mu \mathrm{l}$ were taken for the testosterone assay (or two samples of $50 \mu \mathrm{l}$ for the androstenedione assay) and $100 \mu \mathrm{l}$ for recovery estimation. The recovery values for added $\left[{ }^{3} \mathrm{H}\right]$ testosterone and $\left[{ }^{3} \mathrm{H}\right]$ androstenedione were $89.61 \pm 0.70$ and $85.10 \pm 0.72 \%(\mathrm{mean} \pm$ s.e.m.) respectively.

Milk. Milk samples were warmed to $40^{\circ} \mathrm{C}$ for about $15 \mathrm{~min}$ to liquefy the fat and mixed by vortexing. Testosterone and androstenedione were extracted from the same milk samples $(0.5 \mathrm{ml})$ with diethyl ether $(3 \mathrm{ml})$ after addition of about 1000 c.p.m. $\left[{ }^{3} \mathrm{H}\right]$ androstenedione. The samples were stored at $-20^{\circ} \mathrm{C}$ for some hours to prevent emulsion. The diethyl ether, after separation from the aqueous phase, was evaporated and the residue was dissolved in $1.5 \mathrm{ml}$ of a methanol-water mixture $(7: 3 \mathrm{v} / \mathrm{v})$. This mixture was placed in a $40^{\circ} \mathrm{C}$ bath for $1 \mathrm{~h}$, frozen at $-20^{\circ} \mathrm{C}$ overnight and then centrifuged to eliminate the excess fat. The supernatant was dried and the residue treated as described above for plasma. The recovery of testosterone was calculated in preliminary experiments. The recovery values for added $\left[{ }^{3} \mathrm{H}\right]$ testosterone and $\left[{ }^{3} \mathrm{H}\right]$ androstenedione were 75.75 \pm 1.72 and $76.44 \pm 0.92 \%$ respectively.

\section{Radioimmunoassays}

Androstenedione. The androstenedione RIA was performed using a specific antiserum to $11 \alpha$ hydroxy-androstenedione-11 $\alpha$-hemisuccinate-BSA, raised in a rabbit, at a working dilution of $1: 10000$ and $\left[{ }^{3} \mathrm{H}\right]$ androstenedione $(32 \mathrm{pg} /$ tube) as tracer. The antiserum showed the following cross-reactions $(\%)$ : androstenedione 100 ; testosterone 1.2 ; epitestosterone $0.2 ; 5 \alpha$-dihydrotestosterone and dehydroepiandrosterone 0.1 ; progesterone, pregnenolone, oestrone and cortisol 0.001 . The reagent blank value was $1.80 \pm 0.79 \mathrm{pg} /$ tube. The sensitivity of the assay, defined as the mass of hormone required to suppress the binding of the ${ }^{3} \mathrm{H}$-labelled hormone to $90 \%$ of the binding achieved with no hormone added (B/Bo) was $3.8 \mathrm{pg} /$ tube. The accuracy of the assay, determined by adding known amounts (10 and $100 \mathrm{pg} /$ tube) of androstenedione to plasma and milk samples, was $92.41 \pm 6.42 \%$ (20 determinations). The intra-assay and inter-assay precision, expressed as the coefficient of variation, were respectively 6.7 and $11.0 \%$ (20 determinations).

The plasma androstenedione concentrations were corrected for dilution by the added methanol.

Testosterone. The testosterone RIA was performed using an antiserum to testosterone-3carboxymethyloxime-BSA, raised in a rabbit, at a working dilution of $1: 35000$ and $\left[{ }^{3} \mathrm{H}\right]-$ testosterone $(31 \mathrm{pg} /$ tube) as tracer. The antiserum showed the following cross-reactions (\%): testosterone $100 ; 5 \alpha$-dihydrotestosterone 30.6 ; androstenedione 0.6 ; epitestosterone $<0.1$; dehydroepiandrosterone, progesterone and pregnenolone $<0.01$; oestrone and cortisol $<0.001$. The reagent blank value of the assay was $0.59 \pm 0.27 \mathrm{pg} /$ tube and the sensitivity of the assay was $2.8 \mathrm{pg} /$ tube. The accuracy, the intra-assay and the inter-assay precision, calculated as described above, were respectively $99 \cdot 41 \pm 5 \cdot 37 \%, 5 \cdot 7$ and $10 \cdot 1 \%$. The mathematical treatment of data given by Motta \& Degli Esposti (1981) was used. 


\section{Results}

The plasma levels of androstenedione (Text-fig. 1a) remained fairly constant, ranging between 100 and $200 \mathrm{pg} / \mathrm{ml}$ until about Day 90 of pregnancy, then increased progressively to an average value of about $1400 \mathrm{pg} / \mathrm{ml}$ at about Day 200, and remained static until the end of pregnancy. The milk androstenedione values (Text-fig. $1 \mathrm{~b}$ ) were similar in amount and pattern to those in plasma until about Day 90 . Then the concentrations rose rapidly to reach about $3500 \mathrm{pg} / \mathrm{ml}$ at Day 200 . The milk/plasma androstenedione ratio was $1.08 \pm 0.05$ until Day 90 and $2.40 \pm 0.09$ between Day 90 and the end of lactation $(P<0.001)$.
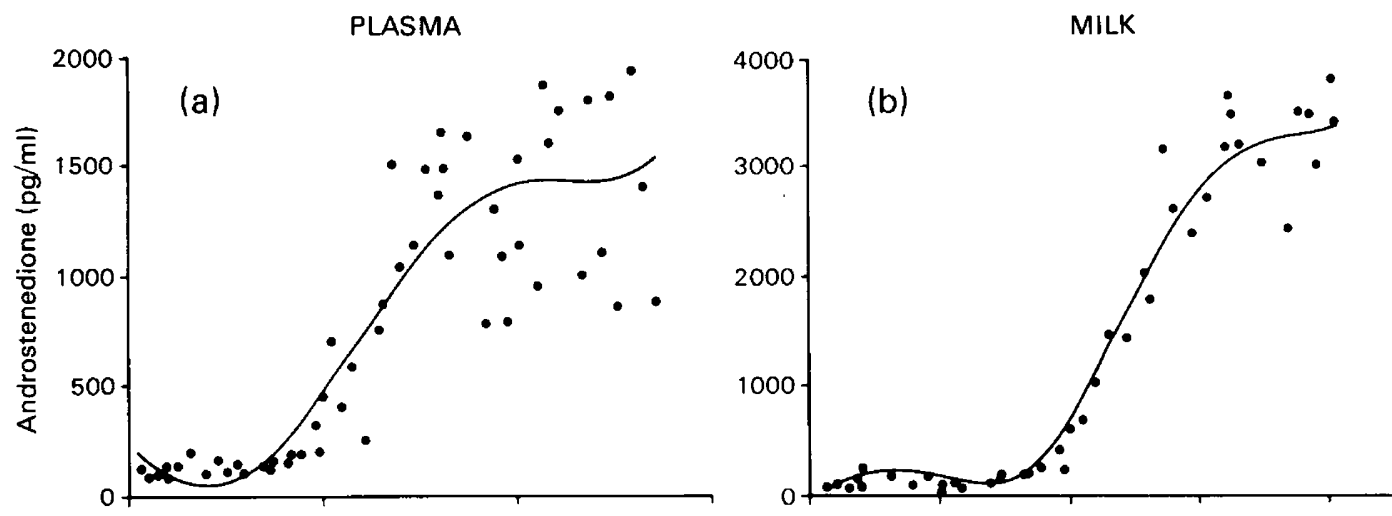

है
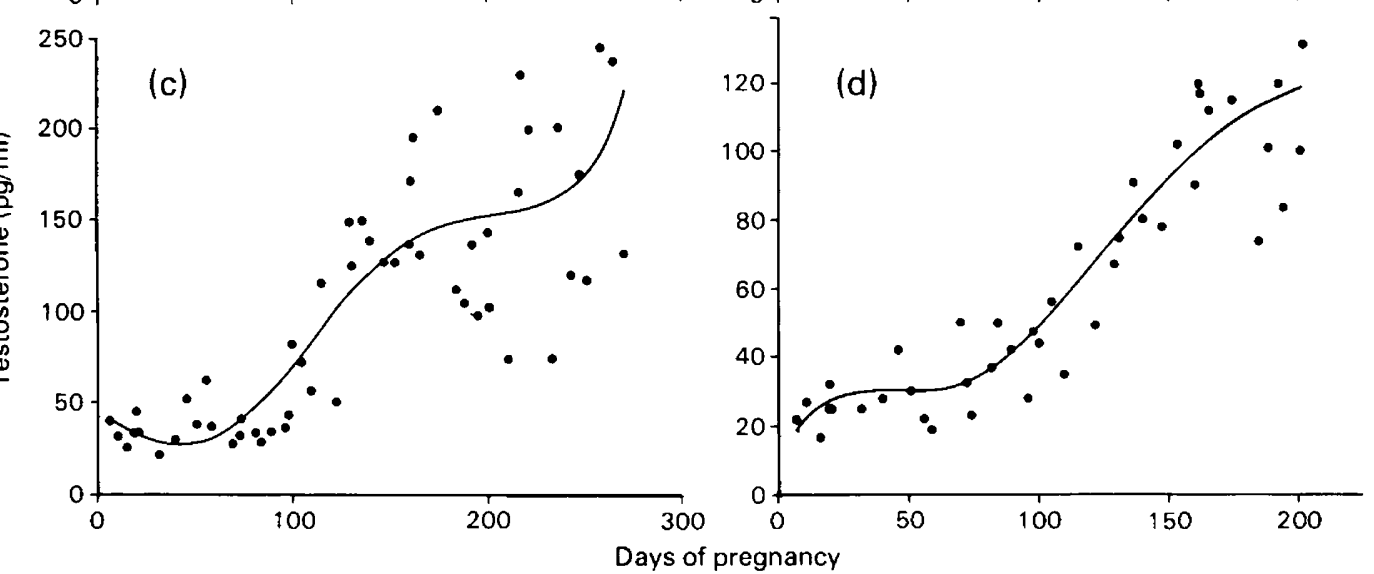

Text-fig. 1. Concentrations of androstenedione $(a, b)$ and testosterone $(c, d)$ in the plasma $(a, c)$ and milk (b, d) of 54 Holstein-Friesian cows throughout gestation (a, c) and until the end of lactation $(b, d)$. The pattern of the hormone concentrations is given by the continuous line which was obtained by means of a polynomial regression of 5 degrees.

Plasma concentrations of testosterone (Text-fig. 1c) ranged between 20 and $50 \mathrm{pg} / \mathrm{ml}$ until about Day 90 of pregnancy, then increased progressively to about $220 \mathrm{pg} / \mathrm{ml}$ around Day 270 . From the beginning of pregnancy, testosterone values in the milk (Text-fig. 1d) showed a slight but continuous increase from $20 \mathrm{pg} / \mathrm{ml}$ to $\sim 120 \mathrm{pg} / \mathrm{ml}$ at the end of lactation. The milk/plasma testosterone ratio, constant throughout pregnancy, was $0.79 \pm 0.05$.

By assuming a linear regression $y=\mathrm{a}+\mathrm{b} t$ of hormone content $(y)$ against time $(t)$, the correlation coefficient $(r)$ and the regression coefficient (b) were found. For the individual hormones the values of $\mathrm{a}, \mathrm{b}$ and $r$ were, respectively: $-136.07,7.01$ and 0.82 for plasma androstenedione; $-828.73,20.99$ and 0.90 for milk androstenedione; $7.60,0.70$ and 0.79 for 
plasma testosterone and $5.56,0.51$ and 0.88 for milk testosterone. Therefore all these hormones were positively correlated with time during gestation. The value of the regression coefficient $b$ showed that milk androstenedione had the highest daily increase while the milk testosterone had the lowest.

The relationship between milk and plasma levels of androstenedione and testosterone from the start of pregnancy to Day 200 was also calculated by a linear regression, which gave the following values for $\mathrm{a}, \mathrm{b}$ and $r$ respectively: $-112.35,2.41$ and 0.96 for androstenedione, and $11.34,0.60$ and 0.86 for testosterone, showing a positive correlation between the hormone concentration in milk and plasma.

The plasma androstenedione and testosterone levels (Text-figs 1a \& 1c) showed great variations among individual animals, particularly after Day 150 . The 24 cows at $6-9$ months of gestation subsequently calved 13 female and 11 male calves. Cows with male fetuses had plasma levels of testosterone and of androstenedione higher than those in cows with female fetuses $(138.00 \pm 13.93$ compared with $179.80 \pm 24.19 \mathrm{pg}$ testosterone/ml; $1167.67 \pm 115.69$ and $1540.70 \pm 196.93 \mathrm{pg}$ androstenedione $/ \mathrm{ml}$ ), but these differences were not statistically significant.

\section{Discussion}

Plasma androstenedione concentrations increased throughout pregnancy in the cow. Plasma testosterone values also increased but were much lower than those of androstenedione. The plasma levels of androstenedione here reported agree with those found by Mongkonpunya et al. (1975) in peripheral blood of heifers at 90, 180 and 260 days of pregnancy and by Möstl et al. (1981) during the last week before parturition, while our data concerning the plasma levels of testosterone were slightly lower than those found by Hoffmann, Wagner \& Gimenez (1976) (330 pg/ml) and by Möstl et al. $(1981)(400 \mathrm{pg} / \mathrm{ml})$ in cows at the end of pregnancy.

Considerable individual variations in plasma testosterone and androstenedione concentrations occurred, particularly after Day 150 of pregnancy. Although Mongkonpunya et al. (1975) and Pflantz et al. (1981) reported that peripheral plasma concentrations of testosterone were slightly higher in cows with male rather than female fetuses, we found no significant difference in the two hormones in cows with male or female fetuses.

The milk androstenedione concentration increased throughout pregnancy, leading to a change in the milk/plasma androstenedione ratio during pregnancy: after Month 3 and until the end of lactation, androstenedione levels in milk were twice as high as those in plasma. A similar pattern has been previously described for the distribution of oestrone in plasma and milk after Month 4 of pregnancy by Gaiani, Mattioli, Galeati \& Chiesa (1982).

Testosterone concentrations in milk increased slightly throughout pregnancy. The milk/plasma testosterone ratio was constant and showed that the concentration of this hormone is always slightly higher in plasma than in milk. The constant partition of testosterone suggests that the different distribution of testosterone between plasma and milk during pregnancy is only due to an equilibrium between the concentrations in plasma and milk. However, the change in androstenedione distribution after the $3 \mathrm{rd}$ month of pregnancy, could be due to the development in the cow mammary gland of an active mechanism of androstenedione transfer from blood into milk, or to synthesis of androstenedione by mammary gland. Maule Walker \& Peaker (1978) reported active mammary synthesis of oestradiol-17 $\beta$ in the goat at term. Mongkonpunya et al. (1975) reported that the androstenedione concentration was higher in blood leaving the placenta on the maternal and fetal sides, suggesting placental synthesis of this hormone in cows.

The role of androgens during cow pregnancy is not clear. It is possible that these hormones are oestrogen precursors according to Ainsworth \& Kennet (1966) and Pierrepoint, Anderson, Griffiths \& Turnbull (1969), who reported that the bovine fetal placental tissue was able to convert androstenedione, testosterone and dehydroepiandrosterone into oestrogens in vitro although this aromatization was of a low order. 
This study was supported by C.N.R. Grant 1983, Gruppo Nazionale Veterinaria.

\section{References}

Ainsworth, L. \& Kennet, J.R. (1966) Steroid hormone transformations by endocrine organs from pregnant mammals. I. Estrogen biosynthesis by mammalian placental preparations in vitro. Endocrinology 79, 875883.

Bamberg, E., Choi, H.S. \& Möstl, E. (1978) In-vitro conversion of androstenedione and its concentration in the peripheral blood of cows during the oestrous cycle. I.R.C.S. Med. Sci. 6, 245.

Gaiani, R., Nannetti, G. \& Mattioli, M. (1979) La concentrazione dell'androstenedione, del testosterone e del diidrotestosterone nel latte e nel plasma durante la gravidanza della bovina. Atti Soc. ital. Sci. vet. 33, 159.

Gaiani, R., Mattioli, M., Galeati, G. \& Chiesa, F. (1982) The relationship between oestrone and oestrone sulphate in the plasma and milk of the cow during pregnancy. Archo vet. ital. 5-6, 86-91.

Hoffmann, B., Wagner, W.C. \& Gimenez, T. (1976) Free and conjugated steroids in maternal and fetal plasma in the cow near term. Biol. Reprod. 15, 126-133.

Lindner, H.R. (1961) Androgens and related compounds in the spermatic vein blood of domestic animals. II. Species-linked differences in the metabolism of androstenedione in blood. $J$. Endocr. 23, 161-166.
Maule Walker, F.M. \& Peaker, M. (1978) Production of oestradiol- $17 \beta$ by the goat mammary gland during late pregnancy in relation to lactogenesis. J. Physiol., Lond. 284, $71 P-72 P$.

Mongkopunya, K., Lin, Y.C., Noden, P.A., Oxender, W.D. \& Hafs, H.D. (1975) Androgens in the bovine fetus and dam. Proc. Soc. exp. Biol. Med. 148, 489493.

Möstl, E., Choi, H.S. \& Bamberg, E. (1980) Rapid conversion of androstenedione into epitestosterone in bovine blood in vitro. I.R.C.S. Med. Sci. 8, 440.

Möstl, E., Möstl, K., Choi, H.S., Dreier, H.K., Stöckl, W. \& Bamberg, E. (1981) Plasma levels of androstenedione, epitestosterone, testosterone and oestrogens in cows at parturition. $J$. Endocr. 89, 251-255.

Motta, M. \& Degli Esposti, A. (1981) A computer program for mathematical treatment of data in radioimmunoassay. Comput. Progr. Biomed. 13, 121-129.

Pflantz, V.M., Stallcup, O.T. \& Kreider, D.L. (1981) Hormone levels of Holstein fetuses and their dams. $J$. Anim. Sci. 53, Suppl. 1, 358, Abstr. 570.

Pierrepoint, C.G., Anderson, A.B.M., Griffiths, K. \& Turnbull, A.C. (1969) Metabolism of $\mathrm{C}_{19}$-steroids by foetal cotyledons from the bovine placenta at term. Res. vet. Sci. 10, 477-479. 